\title{
Queering discourses of coming out in South Africa
}

\author{
Tracey Lee McCormick \\ Department of Applied Communicative Skills, University of Johannesburg, South Africa \\ E-mail: traceym@uj.ac.za
}

\begin{abstract}
The performative act of "coming out" authenticates a homosexual identity and in the South African context the coming out narrative has gained such momentum that it is now regarded as an imperative for closeted homosexuals by the Lesbian and Gay Equality Project (LGEP). However, coming out has been critiqued by queer theorists who argue that it is problematic because it forces a person into an already established identity category, strengthens the regulation of sexual categories and is complicit in the reconstitution of these categories. In this paper, these queer critiques of coming out will be employed in order to explore the question of why a person is compelled to confess to the 'truth' about their homosexuality in South Africa. The data for this exploration is drawn from three non-fiction gay and lesbian books: "Male Homosexuality in South Africa: Identity Formation, Culture and Crises" (1992) by Gordon Isaacs and Brian McKendrick, "Tommy Boys, Lesbian Men and Ancestral Wives: Female Same-Sex Practices in Africa" (2005) by Ruth Morgan and Saskia Wieringa, and "Performing Queer: Shaping Sexualities 1994-2004 - Volume 1" (2005) edited by Mikki van Zyl and Melissa Steyn. The data was analysed using content analysis and the findings show how homosexuality is extricated from negative discourses of abnormality, promiscuity and fraudulence and reformulated into positive discourses associated with identity politics, normality and progress. In such positive discourses, a person is compelled into disclosure because it is viewed as a necessary step to combat homophobia and conservative family and social norms. This paper argues that as long as the coming out narrative is embedded in the positive discourses of progress, health and enlightenment, it will remain immune to critique of the role that it plays in strengthening heterosexuality as unitary and normative. Finally, this paper suggests that refusing to succumb to the pressure of categorisation could potentially undermine the constraints of the homosexual/heterosexual binary on which the categories of male and female are contingent.
\end{abstract}

Keywords: discourse, queer theory, coming out, queer linguistics, South Africa, homosexuality

\section{Introduction}

The performative act of "coming out" authenticates a homosexual identity. In the South African context, coming out has gained such momentum that it is now regarded as an imperative for closeted homosexuals by the Lesbian and Gay Equality Project (LGEP). This is evident in their 
mission statement which states that "[they] are committed to the self-realisation of LGBTI (lesbian, gay, bisexual, transsexual and intersex) people through the building of their grassroots social, political and economic power" (LGEP 2011). In this paper, the following question will be investigated from the perspective of queer theory: "Why is a person compelled to confess to the 'truth' about their homosexuality in South Africa?" The paper will begin with a brief overview of the historical context of coming out both in western and South African contexts. This will be followed by an overview of the coming out narrative from both an identity politics and a queer theory perspective, after which an explanation will be given of the critical tools drawn from queer theory and queer linguistics which were utilised in order to analyse the data. Finally, the presentation of the data is followed by a conclusion containing a summary of the main arguments about the necessity of re-visiting the value of coming out in the South African context.

\section{The context of disclosure}

In 1973, the American Psychiatric Association removed homosexuality as a diagnostic category from the highly influential "Diagnostic and Statistical Manual of Mental Disorders" (DSM). This official acknowledgement that homosexuality was neither a mental illness nor a disease was a turning point in the history of gay and lesbian liberation. No longer was it necessary for a person to have to hide what was perceived as an abnormal sexuality; they could publicly admit to their secret desires. The legitimation of homosexuality by the DSM in the US encouraged research into a variety of positive aspects associated with homosexuality and, in particular, the liberating process of coming out. ${ }^{1}$

In the context of 1970s and 1980s South Africa, which were the darkest days of apartheid, homosexuality remained both a sin and a crime and coming out was a transgressive and politically risky act. In 1982, the first organisation to promote gay rights was established in Johannesburg, namely, The Gay Association of South Africa (GASA). Conway (2009:856) argues that GASA was "expressly apolitical about wider issues in South African society [and ignored] any critique of apartheid or association with black South Africans". In 1982, Simon Nkoli, an anti-apartheid, gay rights and AIDS activist joined GASA. In 1984, Nkoli was arrested, together with 21 other political leaders, and convicted of furthering the aims of the African National Congress (ANC) and the South African Communist Party (SACP). He was sentenced to five years' imprisonment. In 1988, one year after his release from prison, Nkoli founded the non-racial and liberation struggle-aligned Gay and Lesbian Organisation of the Witwatersrand (GLOW) and, together with the Cape Town-based Organisation of Lesbian and Gay Activists (OLGA), successfully lobbied for gay and lesbian rights to be included in the draft Bill of Rights in 1990. OLGA also initiated and won support for a comprehensive charter of gay and lesbian rights which was accepted in 1993 at a national conference of gay and lesbian organisations (Croucher 2002). In December 1994, the National Coalition for Gay and Lesbian Equality (NCGLE) was formed. Initially a coalition of 36 affiliates, it was renamed the Lesbian and Gay Equality Project (LGEP) in 2002 and, between 1997 and 2006, the NCGLE and then the LGEP were responsible for having 16 homophobic laws overturned.

\footnotetext{
${ }^{1}$ Cf. Plummer (1975), Coleman (1982), Cass (1979), Cain (1991), Rust (1993), Elliot (1996) and Gagné et al. (1997).
} 
Research into gay and lesbian issues in South Africa flourished as a result. ${ }^{2}$ At the heart of such research (similar to western research into homosexual issues) was the importance of coming out, not only as an instrument for personal liberation, but as a political tool to aid the growth of the gay and lesbian movement. Research on coming out, whether in a South African context or any other context, is an area of study that never seems to be exhausted. ${ }^{3}$ This is evident in the amount of research on coming out that continues to be produced in academic disciplines that range from geography to sport science. ${ }^{4}$

\section{Research on coming out from an identity politics perspective}

As previously mentioned, the catalyst for research into the various facets of coming out was the removal of homosexuality as a mental illness from the DSM in 1973. Subsequent to the depathologisation of homosexuality, gay and lesbian researchers started investigating coming out as an imperative in the journey to healthy homosexual identity formation (cf. Plummer 1975, Coleman 1982, Cass 1979, Cain 1991, Isaacs and McKendrick 1992, Rust 1993, Gevisser and Cameron 1994, Elliot 1996 and Gagné et al. 1997). For these researchers, the binary tropes of secrecy (the closet) and disclosure (telling the truth or coming out) delimit the debate. On the one hand, to be in the closet refers to not acknowledging one's homosexuality and is associated with cowardice and being in denial. On the other hand, coming out is aligned with discovering one's real identity and public persona as it refers to acknowledging that one is homosexual and then disclosing this to others. From this perspective, a homosexual identity has a true essence, a point of view encapsulated by Rust (1993:53) who writes that

[c]oming out is a process of discovery in which the individual sheds a false heterosexual identity and comes to correctly identify and label her own true essence, which is homosexual.

These researchers conceptualise coming out within a model of identity formation. In the 1970s, this model was linear in construction and coming out was viewed as a single event. However, subsequent models developed in the 1980s and 1990s incorporate the view that coming out is a process that usually follows specific psychological and social stages or involves elements which do not necessarily occur in the same order or at the same pace. According to these models, the coming out process usually starts with a person suspecting that $\mathrm{s} / \mathrm{he}$ is gay; this person then finds a gay or lesbian community and the process ends when he or she has an intimate homosexual relationship (Isaacs and McKendrick 1992).

Contemporary research into the coming out narrative (cf. Chirrey 2003, 2011; Hubbard and De Welde 2003; Rasmussen 2004; Ward and Winstanley 2005; Cuomo 2007; Gorman-Murray 2008; Vaughan and Waehler 2010; Smuts 2011 and Xhonneux 2012) emphasises that coming out differs depending on a person's social, political and economic context and the ambit of

\footnotetext{
${ }^{2}$ Cf. for example Botha and Cameron (1993), De Vos (1994, 1996), Lind (1995), Elder (1995), Stychin (1996), Holmes (1997), Cameron (1997), Kwesi and Webster (1997), Donham (1998), Hoad (1998, 1999), Jara and Lapinsky (1998), Kraak (1998) and Louw (1998).

${ }^{3}$ The fascination with documenting the trials, tribulations and various stages of coming out has not been limited to academia; coming out has entered into popular consciousness in a significant way and there is a wealth of information in the realm of popular culture. This does not mean that coming out is always a seamless process, especially in South Africa where there is a high level of homophobia. A discussion of the perils of coming out in Africa is presented in section 7.2 of this paper.

${ }^{4}$ Cf. Gorman-Murray (2008) and Stoetling (2011).
} 
coming out has been widened to include bisexual and transgendered people. ${ }^{5}$ The coming out dilemma is also presented in a more nuanced and complex way. For example, Chirrey (2003:35) challenged the linguistic understanding of coming out as a speech act which she claimed was limiting because "other, non-linguistic ways of coming out [...] cannot [fit into this] analysis". She proposed instead that coming out should be viewed as a performative act. ${ }^{6}$ Ward and Winstanely (2005:450) argue that coming out as a homosexual exposes the "lack of congruence between the subjectivity of the individual and the subject position that is available for the individual to take up". However, despite the move away from simplistic linear models of coming out to more multi-layered and complex approaches that include subjectivity studies, coming out remains framed by identity. Gorman-Murray (2008:32) encapsulates this approach when he writes that "coming out $[\ldots]$ is the term given to the process of defining oneself as gay/lesbian or bisexual, marking a shift in self-defined sexual identity". ${ }^{7}$ This paper investigates the shortcomings of coming out being linked to a "self-defined sexual identity" (GormanMurray 2008:32). In order to do this, specific critiques from queer theory are used to destabilise the coming out imperative in the South African context.

\section{Explaining queer theory}

Queer theory is not so much a theory but is rather a conceptual field that finds its impetus in post-structuralist reservations about the notion of an 'essential identity'. Queer counterdiscourses were made possible by post-modern reconfigurations of subjectivity as being more flexible and ambivalent rather than fixed and essential (Hennessy 1994/1995). Queer theory attempts to interrogate the pervasiveness of heteronormativity in order to, Berlant and Warner (1998:548) argue, "try to unsettle the garbled but powerful norms supporting [the privilege of the heterosexual couple] including the project of normalization that has made heterosexuality hegemonic". Although queer theory originated in the US in the early 1990s, its influence has spread throughout the world.

The term "queer" does not refer to a natural type or an already established category; it derives its meaning from being dissimilar from the norm (Halperin 1995). Being queer is not restricted to gay and lesbian people; it includes any person who feels that she or he does not belong in normal society. In fact, it refers to whoever is at odds with the norm or to anyone who "rupture[s] or resist[s] [...] normal kinship relations" (Butler 1994:15). In support of the accommodating nature of queer, Butler argues that "queer theory and activism acquired political salience by insisting that antihomophobic activism can be engaged in by anyone, regardless of sexual orientation" (Butler 2004:7).

Prior to the queer theory critique of coming out (explained in the following section), Kosofsky Sedgwick in "The Epistemology of the Closet" (1990) and Halperin in "Saint Foucault:

\footnotetext{
${ }^{5}$ For example, the South African gay and lesbian lifestyle website www.queerlife.com.za has an entire section devoted to gay, lesbian, bisexual and transgender stories on coming out.

${ }^{6}$ Performative acts are linked to the authority of speech; when they are uttered they perform an action that persists. So to pronounce "I am gay" or "I am lesbian" not only performs the action of identifying the person coming out as a homosexual, but it reinforces the heterosexual/homosexual binaries. Performative acts can be viewed as a locale where "power acts as discourse" (Butler 1997a:11, original emphasis).

${ }^{7}$ Halperin (1995) argues that the terms "bisexual", "transgendered" and "intersex" in the BTI part of the LGBTI acronym are often just tacked on. There is, he stresses, little engagement by gay and lesbian movements with the issues that affect people who are bisexual, transgendered or intersex. McLean (2007:164) concurs when she states that because bisexuality is so misunderstood "non-disclosure is often seen as the better alternative".
} 
Towards a Gay Hagiography" (1995) theorised about coming out from a perspective not limited to the fixedness of identity. Rather than promoting coming out as an imperative in order to combat homophobia and the denial of a true homosexual identity, as was the academic trend at the time, Kosofsky Sedgwick concentrates on theorising "the closet" as a space that conceals more than it reveals and is, for her, ultimately paradoxical. This leads to the question as to whether being in the closet means that people treat you as heterosexual because you have succeeded in tricking them or because they know you are really gay or lesbian and they are enjoying their epistemological privilege (Kosofsky Sedgwick 1990, Halperin 1995). For Halperin (1995), coming out means having to submit to a distinctive set of dangers rather than being an exhilarating act of liberation: homophobic people can vent their fantasies on one, and one's body is marked and evaluated as a result of openly admitting one's homosexuality. Halperin argues that this needs to be combated at every opportunity and, therefore, "coming out [may be viewed as] an act of freedom [...] not in the sense of liberation but in the sense of resistance" (Halperin 1995:30).

\section{The queer theory critique of the coming out narrative}

The notion of 'coming out' as a form of resistance rather than liberation shows the influence of Foucault's seminal publication entitled "The History of Sexuality Volume 1" (1976) on queer theorisation. In this book, Foucault shows how the categories of heterosexual and homosexual (and all other deviant sexualities) were constructed as a result of the shift in the control of sexuality from the church to the secular discourses of medicine, education and psychology in the $17^{\text {th }}$ and $18^{\text {th }}$ centuries. Once a category is named, confessed to and the truth about it established, it can be monitored and controlled. Foucault traces how the confession, which was established by the Roman Catholic Church in 1215, has become pervasive in contemporary society; a person is compelled to confess with solemnity that which is the most troublesome to tell in a range of confessional practices ranging from psychotherapy to criminal justice (Foucault 1976). It is in the confession that sex and truth merge. The compulsion to confess is so prevalent that it is no longer viewed as the result of some controlling power; rather, confessing is viewed as a process to uncover a truth that is hidden and that needs to be uncovered and liberated. Kopelson (2002:21), following Foucault, argues that

[s]peaking the 'truth' of one's sexuality, although pervasively viewed as an act of liberation from repressive cultural constraints, more often simply obeys societal mandates to name and confess one's self/sins, and, in so doing, inducts our sexuality into the cultural machinery that can then further constrain and manage it.

Queer theorists, such as Butler (1990, 1997a, 1997b) and Kopelson (2002), argue that the coming out narrative is actually counterproductive as it forces a person into an already established identity category. The identity category of homosexual is supported by a set of narratives that makes sense only by being what the binary heterosexual is not. From a queer perspective then, coming out strengthens the regulation of sexual categories. Butler (1997b:93) refers to coming out as exhausting because whatever one says or does is "seen as a subtle manifestation of [one's] essential homosexuality". She also argues that "sexuality may be said to exceed any definitive narrativisation" (Butler 1990:131) and the impossibility of living up to real identity categories, coupled with the ease with which these categories can be imitated, reveals the problem with viewing gender and sexuality as fixed categories. Halberstam 
(1998:82) concurs when she explains that "the stability of the terms 'male' and 'female' depend on the stability of the homosexual-heterosexual binary".

Kopelson (2002:22) asserts that the coming out narrative has been reduced to a "cultural cliché" that is swiftly losing its power. According to her, it is an act of "simplistic re-presentation" that falls short of disturbing normative identity categories. She argues that this is because coming out is actually complicit in the continual reconstitution of these categories (Kopelson 2002:23). Coming out also makes it impossible to disrupt the binary logic of sexuality and its system of benefits and punishments. Milani (2012:71) further argues that

[e]ven when mobilized towards the achievement of an emancipatory agenda, too much focus on sexual identities can, in the best of cases, only lead to a temporary re-calibration of power inequalities - something that however leaves the homo/heterosexual binary intact.

When a person comes out, he or she enters into a fixed and sanctioned binary system which is incapable of questioning the supposed naturalness of heterosexuality. According to Kopelson (2002), the role of homosexuality has been to bring together a divergent assortment of norms and practices and, whilst heterosexuality is not static, "the project of heterosexuality succeeds because it convinces us that heterosexuality is singular and all-encompassing" (2002:22, original emphasis). The institutions of heterosexuality operate to disseminate heterosexuality as comprehensive and dominant in its significance whilst concurrently diminishing homosexuality as deviant and unimportant. To come out as a homosexual means to become part of an existing and controlled identity that strengthens heterosexuality as unitary and normative (Kopelson 2002). Furthermore, being defined as homosexual means that heterosexuality, as well as the chance to disassemble heterosexual supremacy, is discarded. Butler (1997b) suggests risking "the incoherence of identity" (149, original emphasis) in order to work on "the weakness in heterosexual subjectivation and to refute the logic of mutual exclusion by which heterosexism proceeds" (148). The queer critique of coming out as forcing a person into an already established identity category, strengthening the regulation of sexual categories and being complicit in the reconstitution of these categories destabilises the idea that authenticating a homosexual identity is the most effective way to challenge the assumption of heterosexuality.

As mentioned in the introduction to this paper, research into homosexual issues, specifically that of coming out, burgeoned when homosexuality was associated with mental health. The main concern with regard to research into coming out for writers, ranging from Plummer in the 1970s to Gorman-Murray in the 2000s, is to extract homosexuality from those discourses that associate it with negative stereotypes and inauthenticity and to insert it into positive discourses associated with identity politics, normality and progress. For example, Chirrey (2011:283) describes coming out as being "reasonable, emotionally healthy, moral and loving". In her study, she used script formulation theory to analyse data (in the form of advice given to people who are considering coming out) from six internet sites. She argues that coming out transforms individuals and society and is "what any reasonable person would do" (Chirrey 2011:296). Finally, she claims that positive dispositions are formulated in these advice texts thus "normalizing [gay and lesbian people] as individuals" (Chirrey 2011:296).

Negative discourses about homosexuality circulate widely in society and are coupled with negative stereotypes. Such negative discourses associate homosexuality with what are 
considered negative sexual practices (such as bondage, dominance, sadism and masochism (BDSM), promiscuity and camping) and negative gender performances (such as drag, camp and lesbian butch/femme behaviour). In gay and lesbian research in which identity is privileged, there is an intentional theoretical move to distance negative practices and performances associated with homosexuality from a homosexual identity. Milani (2013a:618) argues that what is normal same-sex desire and what is abject in the pursuit of this ideal should not be ignored, as he elaborates in the following excerpt:

Just as hetero-normativity should be brought under the queer critical spotlight, so too should the processes that normalise and legitimise some expressions of same-sex desire (e.g. monogamous, committed homosexual relationships) while (re)casting others into the domain of abjection (e.g. BDSM and uncommitted, multi-partnered relationships).

\section{The relationship between queer theory and queer linguistics}

The queer theory critique of coming out is such that it forces a person into an already established identity category, strengthens the regulation of sexual categories and is complicit in the reconstitution of these categories. It is this perspective that provides the theoretical framework to approach a critique of coming out in this paper. The methodology utilised here is drawn from queer linguistics in order to carry out a content analysis of the data. Queer linguistics is a "young approach" (Motschenbacher 2011:149) that uses post-structuralist theories (drawn predominantly from, but not limited to, queer theory) to analyse the relationship between language and sexuality. Queer linguistics is a reaction to the trend by sociolinguistic researchers in the 1980s and 1990s to frame the relationship between language and sexuality in essential notions of identity. The study of the relationship between language and (homo)sexuality (also known as the "lavender lexicon") went under various monikers that included "gayspeak", "queerspeak" and "faglish" (Kulick 2000:258).

McCormick (2009) provides an overview and critiques of sociolinguistic research into the lavender lexicon, drawing on the work of Kulick (2000), Cameron and Kulick (2003, 2004, 2005) and Cameron (2005). McCormick explains that the lavender lexicon demonstrates how some gay people use certain lexical items or discourse moves in specific contexts. These items or discourse moves were never shown to be exclusively gay; they could have been generally available linguistic resources and strategies used by any speaker. The findings are consistent with Kulick"s assertion that "[ $t]$ here is no such thing as gay or lesbian language" (2000:247). Locating this insight in the South African context, McCormick (2009) provides an analysis of the discursive construction of gay identity in Cage's (2003) work entitled "Gayle: The Language of Kinks and Queens: A History and Dictionary of Gay Language in South Africa". Her findings show that the unique South African gay language advocated in "Kinks and Queens" does not exist and that this text reproduces normative positions around sexuality and language.

Motschenbacher's (2011) article clearly articulates the scope of queer linguistics. According to him, queer linguistics "deals with the linguistic construction of heteronormativity and its stabilizing mechanism, normative gender binarism" and, when analyzing language, assumes that "(sexual/gendered) identities do not exist pre-discursively but are constructed socially in the very moment of speaking or writing" (Motschenbacher 2011:151, 161). What distinguishes queer linguistics from the lavender lexicon, Motschenbacher argues, is the willingness of queer 
linguists to engage with post-structural theory when analysing the relationship between language and sexuality. He explains that there has been a hesitance by linguists to use poststructural theory which has resulted in "linguistics lagging behind other social sciences as far as the incorporation of poststructuralist and, more specifically, Queer thinking is concerned" (Motschenbacher 2011:150). Queer linguistics uses existing linguistic methodologies in a pluralistic way and combines qualitative and quantitative methods as well as micro perspectives (e.g. ethnomethodology) and macro perspectives (e.g. discourse analysis) in order to attain a "multidimensional analysis" (Motschenbacher 2011:161). Motschenbacher (2011:173) concludes his article by arguing that "it is now time to move beyond foundational debates and to ensure its further consolidation as a veritable field of study".

In the South African context, research by Milani (2012, 2013a, 2013b) is contributing to the growing field of queer linguistics. The unique contribution of this paper to queer linguistics, however, is that it provides a content analysis of three gay and lesbian non-fiction texts in the South African context which, to the author's knowledge, has not been done before.

\section{Data analysis}

In the following sections, I trace the shift from negative to positive discourses surrounding homosexuality in the South African context. The data used to highlight this shift is drawn from three South African non-fiction gay and lesbian books. These three books ${ }^{8}$ were chosen because they reflect specific gay and lesbian concerns in particular historical contexts. For example, "Male Homosexuality in South Africa: Identity Formation, Culture and Crises" (1992) ${ }^{9}$ explains the lack of political interest of white middle-class gay males during the early $1990 \mathrm{~s}$, a time when the gay and lesbian movement in South Africa was developing into a non-racial movement. "Tommy Boys, Lesbian Men and Ancestral Wives: Female Same-Sex Practices in Africa" $(2005)^{10}$ argues for black lesbian rights in Africa and an end to black lesbian-specific violence in South Africa in the early 2000s when there was a political revival of the idea that homosexuality was a colonial import. Finally, "Performing Queer: Shaping Sexualities 19942004 - Volume 1" $(2005)^{11}$ contains a selection of 14 papers by established and emerging black and white, gay and lesbian scholars that explore an array of topics 10 years after the first democratic election in South Africa and the inclusion of the Equality Clause in the Constitution.

\footnotetext{
${ }^{8}$ This paper is based on a chapter from my $\mathrm{PhD}$ thesis. Ten non-fiction gay and lesbian books were written between 1992 and 2008 in South Africa. In my thesis, six of them were analysed: "Male Homosexuality in South Africa: Identity Formation, Culture and Crises" by Isaacs and McKendrick (1992), "Defiant Desire: Gay and Lesbian Lives in South Africa" by Gevisser and Cameron (1994), "Gayle: The Language of Kinks and Queens: A History and Dictionary of Gay Language in South Africa” by Cage (2003), "Tommy Boys, Lesbian Men and Ancestral Wives: Female Same-Sex Practices in Africa" by Morgan and Wieringa (2005), "Performing Queer: Shaping Sexualities 1994-2004 - Volume 1" edited by van Zyl and Steyn (2005) and "To Have and to Hold: The Making of Same-Sex Marriage in South Africa" edited by Judge, Manion and De Waal (2008). From a gay and lesbian rights perspective, coming out is viewed as a milestone in the gay experience and is associated with empowerment and the combating of prejudice, discrimination and violence against sexual minorities. From a queer perspective, coming out is interrogated for being linked to the liberation of the true but repressed self. Coming out also forces a person into the established identity category of "homosexual" and thus works to reinforce and control sexual categories. "Male Homosexuality" (1992), "Tommy Boys" (2005) and "Performing Queer" (2005) provide significant support for this conceptualisation of coming out.

9 Hereafter "Male Homosexuality".

${ }^{10}$ Hereafter "Tommy Boys".

${ }^{11}$ Hereafter "Performing Queer".
} 
What is shown in the data analysis to follow is how not admitting to a homosexual identity is aligned with negative discourses and how coming out is aligned with positive discourses.

\section{1 "Male Homosexuality in South Africa"}

In Isaacs and McKendrick's (1992) book, male homosexual ${ }^{12}$ identity formation is associated with negativity. The authors substantiate this when noting that "the persistent theme that runs through this book is that crisis is associated with homosexual identity formation" (1992:218) and "whether he likes it or not, the homosexual as a marginal person will experience a crisis of identity" (1992:55). The inevitability of trauma for a male homosexual makes "Male Homosexuality" a dour read as page after page describes the very detailed profile of the beleaguered homosexual psyche.

Isaacs and McKendrick argue that such trauma is a result of being in the closet and can be avoided or eased by coming out. On the one hand, coming out is, for the authors, a positive and life changing act and it has real repercussions for the life of a homosexual man. It is for this reason that coming out is collocated with words or phrases such as "successful" (188), "vital" (188), "achieving" (188), "whole sense of self" (188), "ownership" (159), "re-birthing experience" (202) and "gay liberation" (209). On the other hand, the authors believe that remaining in the closet is associated with negative practices and behaviours such as camping and promiscuity. As a result, remaining closeted is collocated with words or phrases such as "denial" (17), "marginal" (55), "erotic" (108), "internalized homophobia" (108), "loss" (108), "incompleteness" (108), “competitiveness" (108), "defilement" (109), "emotional fraudulence" (178) and "bisexuality" (216).

For Isaacs and McKendrick, male homosexuals in South Africa in the late 1980s (when the research was carried out) inhabit a world of clubs and bars where having or procuring sex is the focus of their existence. Such promiscuity is a result, the authors argue, of the persecution of homosexuals by the apartheid state that has instilled fear and self-loathing in homosexual men. The authors explain that " $[\mathrm{t}]$ he repetitive return to sex-searching behaviour that confronts most gay people during their phases of identity consolidation is driven by an anticipated fear" (1992:83) which is the "context within which much homosexual existence occurs" (1992:38).

It is argued here that Isaacs and McKendrick are corrective in their approach to homosexuality because their remedy for the crises of camping and promiscuity hinges on positive discourses associated with coming out. They are embarrassed by the "sex-searching behaviour" (1992:83) of homosexual men and want to distance themselves (and normal homosexual men) from such excess. Before they chart how a positive, healthy and resolved homosexual psyche can be achieved by coming out, they explain in great detail the negative discourses of crises which, it is argued here, are necessary to illustrate the correctness of their intervention. ${ }^{13}$

Isaacs and McKendrick make a direct link between being in the closet and negativity. For them, the closet is a form of "emotional fraudulence [which] perpetuates a sense of prolonged or

\footnotetext{
${ }^{12}$ Isaacs and McKendrick state that their research population is small, mainly white and middle-class and is not "typical of all gays" which "introduces a distinct bias into the study" (Isaacs and McKendrick 1992:169, 172).

13 "Male Homosexuality was written to provide information and training to providers of social services to gay men, and has become a foundational text used in social work classes in at least one major university" (Leatt and Hendricks, in van Zyl and Steyn 2005:304).
} 
incipient crisis" (1992:178). A further link is made between such fraudulence and the "selfdestructive behaviour" associated with "discotheques, steam baths, bars, and camping locations" (1992:212). The "self-destructive behaviour" that Isaacs and McKendrick are referring to here is camping or cruising which they define as "courting, or hustling behaviour to attract attention, specifically to attract a person with the intention of becoming sexually involved" (1992:247). The authors proceed to make an additional link between camping and being in the closet when they write that "camping is linked to 'closet' behaviour and private fantasy experiences, and is often the precursor to gaining access to direct sexual experience with others" (1992:108).

For Isaacs and McKendrick, camping or cruising is highly problematic as it is a ritual for homosexual men who feel incomplete and unhappy because they are in denial about the truth of their sexuality. The authors note that "camping is experienced as a remedy for loss, and sexuality and erotica become the healing components" (1992:108). By intentionally considering camping to be "a remedy for loss", a space is opened up for the authors to describe their corrective remedy. This includes being truthful by coming out to friends, family and work colleagues and by becoming politically active and leading an openly gay life, therefore leading to a "breaking down of social isolation" (1992:178).

According to Isaacs and McKendrick, the dire outcome of hating oneself as a result of having promiscuous sex in order to feel better is that it is impossible to achieve a "whole sense of self" (1992:188). Not being able to achieve this whole sense of self means being a fragmented, detached and isolated one-dimensional homosexual who hates himself. The authors note that "[c]amping is strongly connected to episodes (short- or long-term) of internalized homophobia" (1992:108). The final move by Isaacs and McKendrick in their detailed description of the misery of emotional fraudulence and the wretched life of the promiscuous gay man is to associate camping with "defilement" (1992:109), thus completing the link in the negative chain that begins with being closeted.

Isaacs and McKendrick's corrective approach to homosexuality is epitomised by the coming out narrative; notably, 74 pages out of 231 refer to the different aspects of coming out and 23 full pages are devoted specifically to the topic. Coming out is presented as the primary way in which to activate a stable identity, to bring about change and to end the misery of denial. The authors make it clear that " $[\mathrm{t}]$ he root of the experience is that coming out implies admitting that one is homosexual" (1992:182, original emphasis). Coming out is the first step in the process of developing a holistic homosexual identity. Furthermore, this nuanced process incorporates many positive features such as "openly declaring an allegiance to gay liberation, and coming out to employers, parents, and others" (1992:209).

Isaacs and McKendrick note that it does not matter at what age one comes out as long as one does indeed come out. They state that "[between the ages of 16 and 64] represents the most crucial years for the attainment of a homosexual identity" (1992:90). When a person comes out as a homosexual, their past is erased; coming out, the authors declare, is a "rebirthing experience [that is] imprinted in a person's psyche" (1992:202). Starting afresh by coming out means that a person can consolidate fractured parts of the psyche and become a unified and coherent person. The authors propose that "the successful management [of the coming out process] is vital for the integration of homosexual identity into broader personal identity, thereby achieving a whole sense of self' (1992:188). 
Isaacs and McKendrick view coming out as a liberating and conscious political act. By embedding this act in political discourse, it becomes associated with the positive discourses of development, enlightenment, human rights, truth, progress, empowerment, integrity and dignity. In contrast, to remain in the closet, which "represents an interim denial of homosexual identity" (1992:17), means to be apolitical and closet behaviour is, therefore, linked to the negative discourses of apathy, frivolity, over-sexualisation, filth, fraudulence and crisis.

\section{2 "Tommy Boys"}

In "Tommy Boys" (2005), disclosure is linked not only to the contemporary notion of "coming out' but also to the hidden truth about pre-colonial female same-sex practices in Africa. Morgan and Wieringa argue that coming out as a lesbian in an African context is "very dangerous" (2005:19) and far more complex in comparison to coming out in a western context. As a result, many lesbians in Africa choose not to come out with the result being that " $\mathrm{t}] \mathrm{he}$ silence in which most African women in same-sex relations live their lives causes their marginalisation from society" (2005:19). Furthermore, the authors argue that the pervasiveness of the extended family system in Africa means that out lesbians "may lose whatever support their families afforded them and may be evicted from their homes" (2005:19).

Morgan and Wieringa make it clear that western approaches to identity are problematic in the African context. They state that "[o]ne of the major concerns [they] have is the tendency to essentialise and universalise human experiences by assuming the relevance of 'western' categories to the lives of people elsewhere" (2005:310). The authors believe that such western categories are associated with white middle-class urban lesbians and thus cannot account for the different set of challenges that confronts black rural and urban working-class lesbians in Africa. Another problem for Morgan and Wieringa is that western understandings of homosexuality are "far removed from the life of the Lovedu ${ }^{14}$ rain queen with her hundreds of wives" (2005:281) and hence cannot account for this cultural phenomenon. The authors promote a local rather than a global understanding of homosexuality and thus demonstrate how homosexuality has been practised differently in different African contexts.

Morgan and Wieringa (2005) argue that negative discourses about homosexuality in Africa, where being homosexual is seen as "taboo" (11), "un-African" (11), "an import from the depraved west" (17), "alien to African culture" (17) and "satanic" (20), are a result of colonial governments, post-colonial governments, christianity and patriarchy. ${ }^{15}$ Their project in "Tommy Boys" is to prove how wrong these negative discourses about homosexuality are by providing evidence that female same-sex practices have always existed in Africa.

The first part of Morgan and Wieringa's argument shows the direct homophobic link between colonialism and post-colonialism in which homosexuality is aligned with the taboo and the discourses of satanism and depravity. The second part of their argument shows how, prior to

\footnotetext{
${ }^{14}$ The Lovedu rain queen is the matrilineal queen of the Balobedu people of the Limpopo province in South Africa (Krige and Krige 1981).

${ }^{15}$ A widely held myth in Africa is that homosexuality is a western import and a product of colonialism. The origin of this myth most probably lies with Richard Burton who excluded Africa from his map of the Stotadic Zones in which homosexuality is practised. According to Stanford Pincheon (2000:50-51), this "denial, promulgated by [Burton], has contributed to lingering ideas that same-sex sexual activity, and now a homosexual identification, were not present on the continent".
} 
colonialism, there was a wide variety and tradition of female same-sex practices and even institutionalised marriage between women. The authors note that "women marriages had full rights as citizens of their communities before colonial powers intervened and introduced their own Victorian norms and legal apparatus" (2005:18). In their final argument, Morgan and Wieringa directly link the favourable African past (where female same-sex practices and women marriages were traditional and institutionalised) to the unfavourable contemporary situation of lesbians in Africa. Here they argue that, although homophobia is rife, the participants ${ }^{16}$ in their project are in "loving, caring and enduring same-sex relationships" (2005:313) and that "many of [them] expressed the wish to be able to marry their lovers" (2005:18), as was once allowed before the advent of colonialism.

In their first argument, Morgan and Wieringa seek to counter the claim that homosexuality in Africa is a "western import" (2005:13). They argue that this claim is based on post-colonial leaders in Africa being "ignorant of the fact that a range of same-sex practices in Africa have existed for a long time" (2005:17). They emphatically argue that what links colonialism to postcolonialism is homophobia. This is made clear when they note that "[in] fact homophobia is an idea introduced by missionaries and colonial administrators and copied by post-colonial leaders" (2005:281) and "post-colonial governments perpetuated colonial policies in denouncing same-sex relations" (2005:13). According to the authors, homophobia did not exist prior to colonialism and, thus, the phenomenon is "not based on African culture and history" (2005:281) and is actually, they argue elsewhere, "a perverse distortion of African history" $(2005: 13)$.

Morgan and Wieringa assert that "women's physical expression of their affection for each other" is the primary aspect that "strangers" to Africa, such as "missionaries, colonial administrators and anthropologists" as well as post-colonial leaders, "disapprove of" (2005:282). In support of this line of thought, they draw on the timelessness of tolerance towards homosexuality in Africa in order to remind "present-day post-colonial leaders that Christianity and post-colonial laws with their homophobia are relatively recent western inventions" (2005:320). They respond to the negativity of contemporary homophobia by evoking an African past in which "relations between women [were] perfectly acceptable" but are now aligned with the "abject" (2005:320). ${ }^{17}$

In their second argument, Morgan and Wieringa aim to undo the negative discourses associated with homophobia by constructing an African past where female same-sex practices were accepted and women marriages were institutionalised. ${ }^{18}$ The authors use the work of

\footnotetext{
${ }^{16}$ These participants are lesbians in western, eastern and southern Africa whose testaments were collected by women activists.

${ }^{17}$ In "An Ethnography of Silence: Race, (Homo)Sexualities, and a Discourse of Africa”, Stanford Pincheon (2000:40) argues that the study of homosexualities in Africa abounds with examples of a "limited and unilinear approach" which reinforces social categories. He claims that researchers who research homosexuality in Africa resort to a "circular cluster of arguments" (2000:40) to refute the ahistorical without questioning how such arguments arise. For example, many researchers refer to Africa as a "cultural, social, and political unity" (Stanford Pincheon 2000:41). Further, different periods in African history, such as the pre-colonial, slave trade, colonial and independence movement periods, are referred to in a brief and generalised way. The argument about the pre-colonial existence of homosexuality in Africa, Stanford Pincheon (2000:41) argues, may never be "proved or disproved", yet such arguments constantly arise and will never be exhausted if they remain circular.

${ }^{18}$ Morgan and Wieringa (2005:299) choose to use the term "women marriages" because "it involves the legalised union between two women".
} 
ethnographers such as Karsch-Haack (1911), Falk (1925), Schapera (1930), Herskovits (1937) and Evans-Pritchard (1951) to provide evidence of female same-sex practices and marriages between women in pre-colonial Africa.

Morgan and Wieringa describe a range of female same-sex practices such as homo-erotic play, bond friendships and mummy-baby relations which, they maintain, were "mutual and long lasting and were fully socially accepted" (2005:293). The positive descriptions "mutual", "long lasting" and "acceptance" associated with these friendships contrast directly with how the missionaries saw such friendships. The authors stress that missionaries perceived these friendships as "vice" and, as a result, "set about abolishing them" (2005:293).

The authors argue further that women marriages were fully accepted by different African societies and that they "occurred between powerful women such as rain queens and traditional healers (sangomas)" (2005:17). ${ }^{19}$ Morgan and Wieringa suggest that such "traditional women marriages [were] fully institutionalised in their societies and thus can be seen as normative, non-disruptive same-sex patterns" (2005:319). The authors' emphasis that same-sex couples lived harmoniously side-by-side with heterosexual couples shows how much more openminded pre-colonial Africa was. They reveal how two women living together was normal and not disruptive at all, since female husbands were real women; they were not, Morgan and Wieringa contend, "acting out a drag scene" (2005:320). In other words, the partners in a women marriage did not adopt specific masculine and feminine roles as required by the heteronormative approach to marriage.

Morgan and Wieringa's final move in extracting homosexual practices from negative homophobic discourses is to show the link between the love between women in pre-colonial times and the love between women in post-colonial times. As highlighted above, the authors describe pre-colonial same-sex practices and women marriages in Africa as "loving", "mutual" and "long lasting". Similar qualities are evident for them in post-colonial female same-sex relationships. This is made clear when Morgan and Wieringa declare the aims of their book as "to proclai[m] the right of African women engaged in same-sex relations and practices" and to portray the "joys of having found love" (2005:22).

Not being able express love, Morgan and Wieringa assert, results in these women "feeling alienated from the project of nation building in their countries" $(2005: 17)$ because "all of them would like to become full sexual citizens of their countries" (2005:18). Morgan and Wieringa urge post-colonial leaders to "reflect" on their homophobia and lack of openness that prevent same-sex identified couples from "expressing the love that they feel" because "many of the women dream about marrying their partners and legalising their co-parenting arrangements" (2005:323). Here, the question arises as to whether making marriage the preferred arrangement for queer sexual lives in Africa undermines the diverse array of lesbian-like practices that Morgan and Wieringa reveal in "Tommy Boys". What has been shown in this analysis of "Tommy Boys" is how the authors extract homosexuality from the negative discourses associated with colonial and post-colonial homophobia and insert it into positive discourses associated with rights, citizenship, marriage and love.

\footnotetext{
${ }^{19}$ At no point are Morgan and Wieringa critical of how such women marriages were complicit in upholding the status quo at the time. Bonthuys, a customary law expert, argues that the historical tolerance of these women marriages is "limited by the implicit understanding that such relationships should not question or undermine patriarchal gender roles and heterosexual family structures" (Bonthuys, in Judge et al. 2008:178).
} 


\section{3 "Performing Queer"}

With a title like "Performing Queer", one would expect this book to reflect the theoretical shifts that have occurred in gender and sexuality studies since the early 1990s. Unfortunately, this is not the case. The title, the cover and the three direct references to queer theory by van Zyl, one of the editors of the book, are the most provocative elements in an anthology dedicated to researching gay and lesbian issues in a maturing democracy from an identity politics perspective. ${ }^{20}$

In the introduction, van Zyl makes the aims of the text clear when she says that it investigates sexualities "that do not perform straight" (2005:19) and also shows how identities "can become fixed by processes such as mainstreaming discrete categories which foreclose other possibilities for performing diverse sexual values" (2005:31). Despite this theoretical roominess, the coming out narrative remains central to this text.

Compared to "Male Homosexuality" and "Tommy Boys", the approach to coming out in "Performing Queer" is unique. In "Male Homosexuality"21 and "Tommy Boys", the authors encourage coming out as a political strategy to oppose either homophobic apartheid laws or post-colonial homophobia. Written 11 years after the advent of democracy in South Africa, "Performing Queer" presents coming out as an imperative in fully grasping people's democratic rights. Van Zyl urges people to "come out and identify as lesbian or gay [and] fight for their rights under the constitution" (2005:31).

${ }^{20}$ The cover of the book depicts a black man in a safari suit with a comb tucked into his knee-length sock, a style reminiscent of the way white Afrikaner men dressed in 1970s South Africa, and a white woman wearing a bonnet or "kappie", which evokes the attire of white Afrikaner women during the Great Trek in the mid-19" century. These depictions provocatively parody conservativeness associated with Afrikaner nationalism and apartheid. However, the playfulness and risquéness depicted on the lurid pink cover and the promise in the blurb of an exploration of "queer people's identifications" are not found in any of the 14 papers; instead, these papers are concerned with researching serious gay and lesbian topics.

The covers of "Male Homosexuality" and "Tommy Boys" are not as potentially transgressive compared to "Performing Queer". The cover of "Male Homosexuality" features a painted reproduction of half the face of a well-groomed white man (presumably gay) whose gaze is fixed to the left. As the narrative of the book is about white gay men and the book was written when homosexuality was still illegal in South Africa (hence a painting rather than an actual picture of a man), the cover is consistent with the themes that are developed about homosexuality in the book.

The cover of "Tommy Boys" features a picture of two black women (presumably lesbian) from the waist up. The first woman is wearing boxing training gloves and a white vest and her hands are tucked under her biceps (accentuating them). Her gaze is averted to the left and she looks very stern and strong ("butch" is the best way to describe her). The second woman is leaning lovingly over the first woman, gently clasping her head. She is looking down and she is much smaller and more feminine than the first woman. The picture is a clear depiction of a butch/femme performance by an African black lesbian couple and, as "Tommy Boys" is concerned with the experience of black lesbians in Africa and dedicates a significant part of the book to exploring butch/femme lesbian performances, the cover is consistent with the major themes that are developed in the book.

The only point of rupture vis-à-vis the covers of "Male Homosexuality" and "Tommy Boys" is that the subjects depicted have averted gazes, perhaps indicating an approach to homosexuality in the content of the books that is not "in your face" and does not make the reader feel uncomfortable.

${ }^{21}$ The influence of "Male Homosexuality" on gay and lesbian research in South Africa is acknowledged by various contributors to "Performing Queer". For example, Hattingh's (2005) definitions of "coming out" and being "in the closet" are quoted verbatim from "Male Homosexuality", while Leatt and Hendricks (2005:305) state that "['Male Homosexuality'] is part of a now well-established literature on the development of gay people, their identities and relationships with themselves from infancy to adulthood”. 
Ten out of the 14 papers in "Performing Queer" make direct reference to coming out, but it is that of Hattingh ("Struggles for Authenticity") that dedicates the most space to the process (10 out of 25 pages). His approach to coming out is typical in "Performing Queer" as it is concerned with "gays and lesbians who have come out in their private lives, but remain closeted in the workplace" (2005:196). Like "Male Homosexuality" and "Tommy Boys", the various contributors to "Performing Queer" associate being in the closet with negativity (including shame and cowardice), but they do not ruminate about the crises and negotiation of the various stages of the coming out process. Nevertheless, Hattingh includes another dimension in the coming out dilemma, namely that of passing as a heterosexual. For Hattingh this is an "implicit recognition of inauthenticity" and is an indicator of "neurosis, such as increased loneliness and isolation" (2005:232).

Coming out is presented by the various authors as an "extremely complex" (Hattingh 2005: 212) and nuanced choice that is experienced differently according to the race, religion or health status of a particular individual. Potgieter (2005:187) makes it clear that there is "no one response to "coming out"'. Coming out is further problematised when it is likened to a "project" that is "life-long", the goal of which for the out individual is the "achievement of higher levels of authenticity" (Hattingh 2005:212). Above all, coming out is presented by the various authors as being about identifying with other homosexual people in order to build capacity. Van Zyl declares that "[c]oming out" allows gay people to "identify with others whom we perceive to be "like us" (2005:22) while Nel (2005:295) adds that "encouraging [...] community involvement, whether in existing lgbti structures or in other structures [...] as an 'out' lgbti individual $[\ldots]$ is important".

The coming out narrative in "Performing Queer" is associated with a set of positive discourses that are rooted in constitutional protection. Hattingh (2005:229) argues that the opportunities offered by such protection "represent(s) a call to authenticity". To be "called" to be an authentic homosexual has biblical and military overtones associated with finding one's true purpose in life after leading a life of denial and fraudulence. The positives associated with coming out are further described by various authors with words such as "empower" (Nel 2005:295), "opportunities" (Hattingh 2005:229) and "ownership" (Hattingh 2005:212). However, such positivity is juxtaposed with the significant obligations that come with constitutional protection. Hattingh (2005:229) writes that "[f]reedom also implies that we have a responsibility to take authorship of our lives and to act courageously". As in "Male Homosexuality" and "Tommy Boys", the final and most important step in the coming out process is to go public. ${ }^{22}$ This step brings closure to the remaining negative elements (such as shame and cowardice) associated with being in the closet.

For the purpose of this paper, it is argued here that the presentation of coming out in "Performing Queer", as a democratic right for a responsible gay or lesbian South African citizen, brings to completion the project to distance homosexuality from promiscuity that Isaacs and McKendrick began with the publication of "Male Homosexuality" in 1992. As highlighted in the analysis of this book in section 7.1 of this paper, Isaacs and McKendrick argue that homosexuality is characterised by crisis because it was declared unlawful by the apartheid state. As a result, gay men remain closeted and display self-hatred and self-destructive behaviour

\footnotetext{
${ }^{22}$ Isaacs and McKendrick argue that going public "indicates an overall ownership of identity which moves beyond the private (Isaacs and McKendrick 1992:159, original emphasis).
} 
which manifests in promiscuity and ultimately leads to "feelings of defilement and incompleteness" (Isaacs and McKendrick 1992:109).

Writing 13 years later, when gay and lesbian rights have been enshrined in the Constitution, van Zyl makes it clear that gay men's "pursuit of the self in sex" has been addressed by the safe-sex campaigns prompted by the initial HIV crisis. Van Zyl believes that such campaigns have shifted the pursuit of sex by gay men to "relationships, and the development of sexuality as a social concept relevant to democratisation through egalitarian intimate relationships" (2005:28). To typify queer relationships in a democratic state as being "egalitarian" and "intimate" perhaps explains why there is not a single reference to camping, cruising or promiscuity in the index of "Performing Queer". Hence, another question arises concerning these omissions and why there is a hesitancy to engage theoretically with those performances and practices that are negatively stereotyped but that are an integral part of the robust queer subculture in South Africa. A possible reason for this might be connected to wanting to present a respectable gay or lesbian South African citizen who is free to come out because he or she is protected by the Constitution which is associated with the positive discourses of achievement, empowerment and courage.

\section{Conclusion}

This paper is concerned with questioning the coming out narrative in the South African context through an exploration of data drawn from three non-fiction gay and lesbian books, namely "Male Homosexuality in South Africa: Identity Formation, Culture and Crises" by Isaacs and McKendrick (1992), "Tommy Boys, Lesbian Men and Ancestral Wives: Female Same-Sex Practices in Africa" (2005) by Morgan and Wieringa and "Performing Queer: Shaping Sexualities 1994-2004 - Volume 1" (2005) edited by van Zyl and Steyn. The motivation for this paper is that there is no research in South Africa (to the author's knowledge) that problematises the role that coming out plays in strengthening heterosexuality as unitary and normative. ${ }^{23}$ Rather, coming out is understood as a natural step in healthy identity formation for homosexual people by academics, the gay and lesbian movement, health practitioners and even the progressive public at large. Therefore, the task of this paper was to interrogate the naturalness linked to coming out. Through an investigation of the coming out narrative in these three books, I have exposed those positive discourses that buttress the naturalness linked to coming out, namely identity politics, normality and progress.

Prior to the removal of homosexuality as a diagnostic category from the DSM in 1973, homosexuality was associated with pathology, deviance and abnormality. A definite pattern is discernible in research into homosexuality from the early 1970s in the US, where there was a concerted effort by researchers to distance homosexuality from what is perceived by some as negative practices (e.g. cruising, promiscuity and BDSM) and negative performances (e.g. drag, camp and lesbian butch/femme behaviour) associated with homosexuality. Although research into homosexual issues only really gained momentum in South Africa in the early 1990s, there is a similar research pattern present. This has been explicated in the analysis of the data as in all three of the selected books, coming out is aligned with politicisation, re-birth, stability, success, wholeness, marriage, sexual citizenship, love, normality, democracy, rights, authenticity, empowerment, community and equality. In contrast, being in the closet is linked

\footnotetext{
${ }^{23}$ The queer research by Kotze (2012) into coming out in South Africa focuses on the distinction between coming out as an act liberation and coming out as an incitement to discourse.
} 
to fraudulent behaviour, promiscuity, crisis, cruising, camping, abjection, neurosis, filth, denial, internalised homophobia and the homophobia enacted by colonial and post-colonial governments in Africa.

Whilst being cognisant of homophobia in South Africa, where coming out is viewed as a political tool to combat hatred and prejudice, the work of this paper has been to ask questions about the act of coming out which is seen to be beyond critique. This paper further proposes that future research into a politics of difference in South Africa could investigate how resisting categorisation might undermine the constraints of the homosexual/heterosexual binaries on which the categories of male and female are dependent. Halberstam (1998:53) argues that "resistance has to go beyond the taking of a name ('I am lesbian'), and must produce new forms of being by assuming and empowering a marginal positionality". Questioning coming out narratives and their alleged political purchase might endow us with such a positionality.

\section{Acknowledgements}

I would like to thank the University of Johannesburg for their continued support of my queer research. Thanks also to Professor Tommaso Milani for his reading of this manuscript and Cathy Burton for editing it. Finally, I would like to thank the supervisors of my PhD, Dr Carolyn McKinney and Dr Ann Smith for their insights into the chapter of my thesis that eventually became this paper.

\section{References}

Berlant, L. and M. Warner. 1998. Sex in public. Critical Inquiry 24(2): 547-566.

Botha, K. and E. Cameron. 1993. Sexual privacy and the law. South African Human Rights and Labour Law Yearbook. pp. 219-227.

Bonthuys, E. 2008. The civil union act: More of the same. In M. Judge, A. Manion and S. De Waal (eds.) To have and to hold: The making of same-sex marriage in South Africa. Auckland Park: Jacana Media. pp. 171-181.

Butler, J. 1990. Gender trouble: Feminism and the subversion of identity. New York: Routledge.

Butler, J. 1994. Against proper objects. Differences: A Journal of Feminist Cultural Studies 6(2/3): 1-26.

Butler, J. 1997a. Critically Queer. In S. Phelan (ed.) Playing with fire: Queer politics, queer theories. New York: Routledge. pp. 11-30.

Butler, J. 1997b. The psychic life of power: Theories in subjection. Stanford: Stanford University Press.

Butler, J. 2004. Undoing gender. New York: Routledge. 
Cage, K. 2003. Gayle: The language of Kinks and Queens: A history and dictionary of gay language in South Africa. Houghton: Jacana Media.

Cain, R. 1991. Disclosure and secrecy among gay men in the United States and Canada: A shift in views. Journal of the History of Sexuality 2(1): 25-45.

Cameron, D. and D. Kulick. 2003. Introduction: Language and desire in theory and practice. Language \& Communication 23(2): 93-105.

Cameron D. and D. Kulick. 2004. Language and sexuality. Cambridge: Cambridge University Press.

Cameron D. and D. Kulick. 2005. Identity crisis? Language \& Communication 25(2): 107-125.

Cameron D. 2005. Language, gender, and sexuality: Current issues and new directions. Applied Linguistics 26(4): 482-502.

Cameron, E. 1997. Sexual orientation and the constitution: A test case for human rights. South African Law Journal 110(3): 450-472.

Cass, V. 1979. Homosexuality identity formation. Journal of Homosexuality 4(3): 219-235.

Chirrey, D.A. 2003. 'I hereby come out': What sort of speech act is coming out? Journal of Sociolinguistics 7(1): 24-37.

Chirrey, D.A. 2011. Formulating dispositions in coming out advice. Discourse Studies 13(3): 283-298.

Coleman, E. 1982. Developmental stages of the coming out process. In J.C. Gonsiorek (ed.) Homosexuality and psychotherapy: A practitioner's handbook of affirmative models. New York: Haworth Press. pp. 31-42.

Conway, D. 2009. Queering apartheid: The National Party's 1987 'gay rights' election campaign in Hillbrow. Journal of Southern African Studies 35(4): 849-863.

Croucher, S. 2002. South Africa's democratisation and the politics of gay liberation. Journal of Southern African Studies 28(2): 315-330.

Cuomo, C. 2007. Dignity and the right to be gay. Philos Stud 132: 75-85.

De Vos, P. 1994. The right of a lesbian mother to have access to her children: Some constitutional issues. South African Law Journal 111: 687-694.

De Vos, P. 1996. On the legal construction of gay and lesbian identity and South Africa's transitional Constitution. South African Journal on Human Rights 12(2): 265-290.

Donham, D.L. 1998. Freeing South Africa: The 'modernization' of male-male sexuality in Soweto. Cultural Anthropology 13(1): 3-21. 
Elder, G. 1995. Of moffies, kaffirs and perverts: Male homosexuality and the discourse of the moral order in the apartheid state. In D. Bell and G. Valentine (eds.) Mapping desire. London: Routledge. pp. 50-58.

Elliot, M. 1996. Coming out in the classroom: A return to the hard place. College English 58(6): 693-708.

Evans-Pritchard, E.E. 1951. Kinship and marriage among the Nuer. Oxford: Oxford University Press.

Falk, K. 1925. Homosexualität bei den Eingeborenen in Südwest-Afrika. Archiv für Menschenkunde 1: 202-214.

Foucault, M. 1976. The history of sexuality volume 1: The will to knowledge. London: Penguin.

Gagné, P., R. Tewksbury and D. McGaughey. 1997. Coming out and crossing over: Identity formation and proclamation in a transgender community. Gender and Society 11(4): 478-508.

Gevisser, M. and E. Cameron (eds.) 1994. Defiant desire: Gay and lesbian lives in South Africa. Johannesburg: Ravan Press.

Gorman-Murray, A. 2008. Queering the family home: Narratives from gay, lesbian and bisexual youth coming out in supportive family homes in Australia. Gender, Place and Culture 15(1): 31-44.

Halberstam, J. 1998. Female masculinity. Durham and London: Duke University Press.

Halperin, D. 1995. Saint Foucault: Towards a gay hagiography. Oxford: Oxford University Press.

Hattingh, C. 2005. Struggles of authenticity. In M. van Zyl and M. Steyn (eds.) Performing queer: Shaping sexualities 1994-2004 - Volume 1. Cape Town: Kwela Books. pp. 195-234.

Hennessy, R. 1994/1995. Queer visibility in commodity culture. Cultural Critique 29: 31-76.

Herskovits, M.J. 1937. A note on 'women marriage' in Dahomey. Africa: Journal of the International African Institute 10(3): 335-341.

Hoad, N. 1998. Tradition, modernity and human rights: An interrogation of contemporary gay and lesbian rights' claims in Southern African nationalist discourses. Development Update 2(2): $32-42$.

Hoad, N. 1999. Between the white man's burden and the white man's disease: Tracking lesbian and gay human rights in Southern Africa. GLQ: A Journal of Lesbian and Gay Studies 5(4): 559-584.

Holmes, R. 1997. Queer comrades: Winnie Mandela and the moffies. Social Text 52/53: 161180 . 
Hubbard, E.A. and K. De Welde. 2003. "I'm glad I'm not gay!" Heterosexual students' emotional experience in the college classroom with a 'coming out' assignment. Teaching Sociology 31(1): 73-84.

Isaacs, G. and B. McKendrick. 1992. Male homosexuality in South Africa: Identity formation, culture and crises. Cape Town: Oxford University Press.

Jara, M. and S. Lapinsky. 1998. Forging a representative gay liberation movement in South Africa. Development Update 2(2): 44-54.

Judge, M., A. Manion and S. De Waal (eds.) 2008. To have and to hold: The making of samesex marriage in South Africa. Auckland Park: Jacana Media.

Karsch-Haack, F. 1911. Das Gleichgeschlechtliche Leben der Naturvölker. New York: Arno Press.

Kopelson, K. 2002. Dis/integrating the gay/queer binary: 'Reconstructed identity politics' for a performative pedagogy. College English 65(1): 17-35.

Kosofsky Sedgwick, E. 1990. The epistemology of the closet. Berkeley: University of California Press.

Kotze, E.S.G. 2012. Lesbians' coming-out stories as confessional practices: Liberatory politics or an incitement to discourse? Unpublished Master's research report: University of the Witwatersrand.

Kraak, G. 1998. Class, race, nationalism and the politics of identity: A perspective from the south. Development Update 2(2): i-xii.

Krige, J. and E. Krige. 1981. The realm of a rain queen: A study of the pattern of Lovedu society. Pietermaritzburg: University of Kwazulu-Natal Press.

Kulick, D. 2000. Gay and lesbian language. Annual Review of Anthropology 29: 243-285.

Kwesi, B. and N. Webster. 1997. Black, lesbian and speaking out. Agenda 13(36): 90-93.

Leatt, A and G. Hendricks. 2005. Beyond identity politics: Homosexuality and gayness in South Africa. In M. van Zyl and M. Steyn (eds.) Performing queer: Shaping sexualities 1994-2004 Volume 1. Cape Town: Kwela Books. pp. 303-322.

Lesbian Gay Equality Project (LGEP). 2011. Available online: http://www.equality.org.za/index.php/about (Accessed 6 May 2011).

Lind, C. 1995. Sexual orientation, family law and the transitional constitution. South African Law Journal 112(3): 481-502. 
Louw, R. 1998. Gay and lesbian sexualities in South Africa: From outlawed to constitutionally protected. In L.J. Moran, D. Monk and S. Beresford (eds.) Legal queeries: lesbian, gay and transgender legal matters. London: Cassell. pp. 137-154.

McCormick, T.L. 2009. A queer analysis of the discursive construction of gay identity in 'Gayle: The language of kinks and queens: A history and dictionary of gay language in South Africa (2003)'. Southern African Linguistics and Applied Language Studies 27(2): 149-161.

McLean, K. 2007. Hiding in the closet? Bisexuals, coming out and the disclosure imperative. Journal of Sociology 43(2): 151-166.

Milani, T.M. 2012. Queering the matrix? Language and identity troubles in HIV/AIDS contexts. SPiL Plus 41: 59-75.

Milani, T.M. 2013a. Are 'queers' really 'queer'? Language, identity and same-sex desire in a South African online community. Discourse \& Society 24(5): 615-633.

Milani, T.M. 2013b. Expanding the queer linguistic scene: Multimodality, space and sexuality at a South African university. Journal of Language and Sexuality 2(2): 206-234.

Morgan, R. and S. Wieringa. 2005. Tommy boys, lesbian men and ancestral wives: Female same-sex practices in Africa. Johannesburg: Jacana Media.

Motschenbacher, H. 2011. Taking queer linguistics further: Sociolinguistics and critical heteronormativity research. International Journal of the Sociology of Language 212: 149-179.

Nel, J. 2005. Moving from rhetoric to creating the reality: Empowering South Africa's lesbian and gay community. In M. van Zyl and M. Steyn (eds.) Performing queer: Shaping sexualities 1994-2004 - Volume 1. Cape Town: Kwela Books. pp. 281-302.

Plummer, K. 1975. Sexual stigma: An interactionist account. London: Routledge and Kegan Paul.

Potgieter, C. 2005. Sexualities? Hey, this is what black, South African lesbians have to say about relationships with men, the family, heterosexual women and culture. In M. van Zyl and M. Steyn (eds.) Performing queer: Shaping sexualities 1994-2004 - Volume 1. Cape Town: Kwela Books. pp. 177-194.

Queerlife. 2013. Available online: http://www.queerlife.co.za/test/ (Accessed 22 October 2013).

Rasmussen, M.L. 2004. The problem of coming out. Theory into Practice 43(2): 144-150.

Rust, P.C. 1993. 'Coming out' in the age of social constructionism: Sexual identity formation among lesbian and bisexual women. Gender and Society 7(1): 50-77.

Schapera, I. 1930. The Khoisan peoples of South Africa. London: Routledge. 
Smuts, L. 2011. Coming out as a lesbian in Johannesburg, South Africa: Considering intersecting identities and social spaces. South African Review of Sociology 42(3): 23-40.

Stanford Pincheon, B. 2000. An ethnography of silence: Race, (homo)sexualities, and a discourse of Africa. African Studies Review 43(3): 39-58.

Stoetling, S. 2011. Disclosure as an interaction: Why lesbian athletes disclose their sexual identities in intercollegiate sport. Journal of Homosexuality 58(9): 1187-1210.

Stychin, C.F. 1996. Constituting sexuality: The struggle for sexual orientation in the South African Bill of Rights. Journal of Law and Society 23(4): 455-483.

Van Zyl, M. 2005. Shaping sexualities - per(trans)forming queer. In M. van Zyl and M. Steyn (eds.) Performing queer: Shaping sexualities 1994-2004 - Volume 1. Cape Town: Kwela Books. pp. 19-38

Van Zyl, M. and M. Steyn. (eds.) 2005. Performing queer: Shaping sexualities 1994-2004Volume 1. Cape Town: Kwela Books.

Vaughan, M.D. and C.A. Waehler. 2010. Coming out growth: Conceptualizing and measuring stress-related growth associated with coming out to others as a sexual minority. Journal of Adult Development 17: 94-109.

Ward, J. and D. Winstanely. 2005. Coming out at work: Performativity and the recognition and renegotiation of identity. The Sociological Review 53(3): 447-475.

Xhonneux, L. 2012. The classic coming out novel: Unacknowledged challenges to the heterosexual mainstream. College Literature 39(1): 94-118. 